\title{
25 Research Soure \\ Climate change in MATOPIBA region of Brazil using Thornthwaite (1948) classification
}

\section{LUCAS Eduardo OLIVEIRA-APARECIDO ( $\square$ ledoap@gmail.com )}

Universidade de Sao Paulo https://orcid.org/0000-0002-4561-6760

Alexson Filgueiras Dutra

Federal University of Piauí

Pedro Antonio Lorençone

Graduate Program in Agronomy - IFMS Campus de Naviraí

Francisco de Alcântara Neto

Federal University of Piaui

João Antonio Lorençon

Graduate Program in Agronomy - IFMS Campus de Naviraí

Marcos Renan Lima Leite

Graduate Program in Agronomy, Federal University of Piauí

\section{Research Article}

Keywords: Temperature, rainfall, climate variability, climate extreme index, northeast of Brazil

Posted Date: April 19th, 2021

DOI: https://doi.org/10.21203/rs.3.rs-428799/v1

License: (c) (i) This work is licensed under a Creative Commons Attribution 4.0 International License.

Read Full License 


\section{Abstract}

Identify the climatic characterization of a region and its spatial and temporal variation, as well as its changes in the face of climate change events, is essential for agrometeorological studies because they can assist in the planning of strategies that reduce the negative impacts generated in the cultures exposed to critical climatic conditions. Thus, this study aimed to characterize the climatic conditions of the MATOPIBA region and its changes in scenarios of climate change using the classification index of Thornthwaite (1948). Daily time series of rainfall and temperature data in the 1950-1990 period were used, arranged in a $0.25^{\circ} \times 0.25^{\circ} \mathrm{grid}$, covering 467 points over the studied region. The data set was used to estimate climatological water balance and climate index Thornthwaite (1948), and obtain the trends climatological according to IPCC (2014) climate change projections, with changes in the average air temperature $\left(+1.5^{\circ} \mathrm{C}\right.$ and $\left.-1.5^{\circ} \mathrm{C}\right)$ and precipitation $(+30 \%$ and $-30 \%)$. The MATOPIBA region is characterized by its humid, dry subhumid, and Moist subhumid climate, with the rainy seasons, between October and April, and drought, from May to September, well defined. In MATOPIBA climate change scenarios, climatic extreme indices tend to alter the pattern, frequency, and distribution of climate class, which can increase climate risk and impact crop production. Therefore, the results obtained can be used to develop strategies to mitigate the vulnerability of crops to climate change conditions.

\section{Introduction}

The Brazilian Cerrado, edaphically characterized by wide territorial extension, flat topography, deep soils with low fertility and high acidity, had and continues to play a key role in the development and expansion of Brazilian agriculture in the national and international agricultural scenario (Vendrame et al. 2013). Epicenter of the rapid agricultural expansion mediated by soybean culture, the MATOPIBA region is a continuous area, represented by parts of the Cerrado of the states of Maranhão, Tocantins, Piauí, and Bahia, established in 2015 by Federal Decree 8,447 (Araújo et al. 2019; Rauch et al. 2019).

This Cerrado region is responsible for an important portion of the Brazilian grain production, where the main agricultural commodities (soybean and corn) stand out in the cultivation areas. Also producing cotton, rice and beans, the MATOPIBA region produced $10.22 \%$ of the country's total grains in the 2019/2020 harvest, corresponding to 23.00 million tons, which are mostly destined for the international market (Conab 2020; Silva et al. 2020). However, in recent years, these cultivation areas have been impacted by climatic oscillations intensified by rising temperatures and changes in the frequency and intensity of rainfall. The water deficit is common in this region during the summer that negatively affects the growth and development of plants. In this condition, impacts can affect the establishment of the crop after planting and when it reaches the flowering or grain filling stage, it significantly compromises agricultural production (Reis et al. 2020; Zilli et al. 2020; Wang et al. 2020).

Climatic condition is one of the factors that most influence agricultural activity in a region (Halder et al. 2020). For its identification is necessary to analyze the atmospheric elements that condition the climate of a given locality, being the elements precipitation and air temperature determine the favorable climatic 
conditions for agricultural crops. Water and air temperature are fundamental factors for plant growth and production, because they participate in processes that affect the photosynthetic rate (Taiz et al. 2017). These elements regulate the opening of plant stomatas, affecting the transpiration and respiration processes, causing, under extreme conditions, a reduction in the rate of $\mathrm{CO}_{2}$ assimilation and the remobilization of stored carbohydrates to tissues of greater demand, affecting the development and plant production (Silva et al. 2020).

In this sense, the characterization of climatic conditions and their seasonal occurrence in a given region can be strategies to aid in agricultural planning because it is a tool that allows delimiting regions with favorable climatic conditions for agricultural and non-favorable for the cultivation of plants (Tavares et al. 2018; Wang et al. 2019). To carry out the climatic classification, the frequently used methods involve the indices of Koppen and Geiger (1928), Thornthwaite (1948), and Thornthwaite and Mather (1955).

The method by Thornthwaite and Mather (1955) is considered an efficient system in the characterization of different climatic areas because uses the climatological water balance index (CWB) (Elguindi et al. 2014; Rolim and Aparecido 2015; Sun et al. 2017), which makes the method sensitive in the detection of small spatial variations and allows to obtain in a practical and simplified way the storage of water in the soil (Cetin et al. 2020). Therefore, its use in agriculture is considered adequate because it considers the plant as a physical medium, since it conducts water from the soil to the atmosphere through transport mechanisms, relating the water needs of the crop to the climatic conditions of the region (Rolim et al. 2007).

Studies of climatic characterization that use the method of Thornthwaite and Mather (1955) are fundamental for the understanding of the regions climate, which allows the expansion of new areas of cultivation and the optimization of the productivity of the cultures. However, these studies for the MATOPIBA region are scarce. Thus, we aimed to characterize the climatic conditions of the MATOPIBA region and its changes in scenarios of climate change using the classification index of Thornthwaite (1948).

\section{Material And Methods}

\subsection{Study area and climate dataset}

The study was performed in the MATOPIBA region (Fig. 1), corresponding to part of the Brazilian Cerrado, with approximately 249,665 $\mathrm{km}^{2}$, which includes 337 municipalities with approximately 6 million inhabitants, of which 2 million are residents in the rural area (IBGE 2010). To cover the entire MATOPIBA region, climatic data were collected from 1950 to 1990 for the 467 municipalities in the states of Maranhão, Tocantins, Piauí, and Bahia, inserted in this region. Air temperature data $\left(T,{ }^{\circ} \mathrm{C}\right)$ and rainfall $(\mathrm{R}$, $\mathrm{mm}$ ) were collected in the Meteorological Database for Teaching and Research (MDTR) of the National Institute of Meteorology of Brazil - INMET (Brazil 1992). 


\subsection{Reference evapotranspiration and climatological water balance}

The reference evapotranspiration (ETo) was calculated using the method of Thornthwaite (1948), following equations $1-6$.

$$
E T_{p}=-415.85+23.24 T-0.43 T^{2} \text { for } T \geq 26.5^{\circ} \mathrm{C}
$$

1

$$
\mathrm{ET}_{\mathrm{p}}=16\left(\frac{10 \mathrm{~T}}{\mathrm{I}}\right)^{\mathrm{a}} \text { for } 0^{\circ} \mathrm{C} \leq \mathrm{T} \text { cript }>
$$

2

$$
I=(0.2 \times T a)^{1.514}
$$

3

$$
a=0.4924+1.79 \times 10^{-2} I-7.71 \times 10^{-5} I^{2}+6.75 \times 10^{-7} I^{3}
$$

4

$$
\operatorname{Cor}=\left(\frac{N D}{30}\right) \times\left(\frac{N}{12}\right)
$$

$$
E T o=E T_{p} \times C o r
$$

6

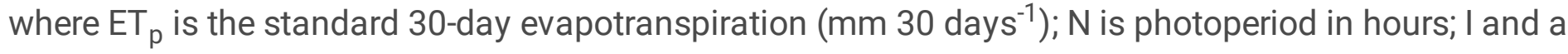
are thermal indices; $\mathrm{T}$ is the average temperature for a given day or period $\left({ }^{\circ} \mathrm{C}\right)$; $\mathrm{Ta}$ is the climatological normal annual temperature $\left({ }^{\circ} \mathrm{C}\right)$; Cor is the correction factor; ND is the number of days, and ETo is reference evapotranspiration $\left(\mathrm{mm}\right.$ day $\left.^{-1}\right)$.

The climatological water balance (CWB) was estimated for all studied locations, according to the methodology established by Thornthwaite and Mather (1955) (Fig. 2). The maximum available water capacity in the soil of $100 \mathrm{~mm}$ was used as a parameter, commonly used, for the purposes of regional climatic characterization (Carvalho et al. 2010; Rodrigues et al. 2018).

\subsection{Classification of Thornthwaite (1948)}


In the climate classification system of Thornthwaite (1948), reference values were used for the CWB extract, using the annual surplus (SUR year), annual water deficiency (DEF annual) and annual evapotranspiration (PET year) in millimeters $\left(\mathrm{mm}\right.$ year $\left.{ }^{-1}\right)$. These combined variables resulted in the four criteria used for classification (Fig. 3).

The first criterion corresponds to the adequacy of humidity (first letter of classification) responsible for determining the nine major climatic types, obtained by calculating the water index (Im, \%), indicating the relationship between excess water and water need. The second criterion (second letter of classification) represents the seasonal distribution of humidity, determining the climatic subclass of the region, for the water factor, through the aridity index equation (la, \%) that relates the water deficit and water need and humidity (Ih). Equations 7 at 9 were used to obtain water (Im), aridity (la) and humidity (Ih) indices.

$$
\operatorname{Im}=\mathrm{Ih}-0.6 \times \operatorname{Ia}
$$

7

$$
\mathrm{Ia}=\left(\frac{\text { DEFyeaar }}{\text { ETPyear }}\right) \times 100
$$

8

$$
\mathrm{Ih}=\left(\frac{\text { SUTyear }}{\text { PETyear }}\right) \times 1
$$

9

The adequacy of the second class was performed according with water deficit (DEFwinter, DEFsummer) and water surplus (SURwinter, SURsummer) for the seasons summer ( $\triangle D E C+J A N+F E B+\triangle M A R$ ) and

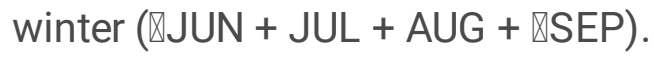

O terceiro e o quarto critério foram responsáveis por adequar os valores de características termais da região. Para isso, utilizou-se do cálculo da eficiência térmica que relaciona a evapotranspiração potencial anual (PETyear) e concentração da eficiência térmica no verão (PETsummer), resultando na evapotranspiração potencial no verão (Equation 10).

The third and fourth criteria were responsible for adjusting the values of thermal characteristics of the region. For that, we used the thermal efficiency calculation that relates the potential annual evapotranspiration (PETyear) and concentration of thermal efficiency in summer (PETsummer), resulting in potential evapotranspiration in summer (Equation 10).

$$
\text { PETR }=\left(\frac{\text { PETsummer }}{\text { PETyear }}\right) \times 100
$$




\subsection{Climatic sensitivity}

Climatic sensitivity was developed by change the average air temperature $\left({ }^{\circ} \mathrm{C}\right)$, in $+1.5^{\circ} \mathrm{C}$ and $-1.5^{\circ} \mathrm{C}$, and rainfall (mm), in $+30 \%$ and $-30 \%$ (Fig. 4), according to methodology of Pirttioja et al. (2015). These values of air temperature and rainfall are future projections reported by IPCC (2014), which make it possible to assess possible changes in future climate and possible impacts on climatic parameters, making it possible to analyze how changes in air temperature and rainfall can influence the climatic classification of the MATOPIBA region.

\subsection{Results spatialization}

Through the geographic information system was performed the spatial interpolation of all climatic elements for all locations using Kriging method (Krige 1951), with spherical model, a neighbor and a spatial resolution of $0.25^{\circ}$, and the system of Albers' equivalent conical cartographic projection. With the overlapping of the maps was possible obtain the climatic maps for the classifications of Thornthwaite (1948). The development of all the analyzes used in the work followed the steps informed in the flowchart in Fig. 5.

\section{Results And Discussion}

Average annual air temperatures in the MATOPIBA region vary from 19.8 to $29.1^{\circ} \mathrm{C}$ (Fig. 6). June (Jun) and July (Jul) are the months with the lowest air temperature, with values between 20 and $21^{\circ} \mathrm{C}$ in the southern portion of the region, located mainly in the extreme West of the Bahia state, and of 24 at $28{ }^{\circ} \mathrm{C}$ in portion Center-West and Center-North of MATOPIBA (Figs. 6F and 6G). Elevated temperatures, above 30 ${ }^{\circ} \mathrm{C}$, are frequent between September (Sep), October (Oct), and November (Nov) in the Center-North and Northwest portion of MATOPIBA, where the states of Maranhão, Tocantins, and Piauí are located (Figs. 6I, $6 \mathrm{~J}$, and $6 \mathrm{~K}$ ). During this period, the occurrence of high temperatures coincides with the higher incidence of solar radiation and lower precipitation, which causes heating of the atmosphere through the emission of long-wave radiation on Earth (Reis et al. 2020). On the other hand, the low temperatures recorded in Jun and Jul can are associated with a lack of precipitation and the consequent reduction in air humidity, which causes less absorption of long wave radiation into the atmosphere at night (Reis et al. 2020).

The average air temperature is an abiotic factor that influences the agricultural activity of MATOPIBA because the plants are grown between October (Oct) and April (Apr), a period with high temperatures, where the plants can suffer stress that result in damage physiological, and less growth affecting, consequently, production. For soybeans, the main crop in the region, high temperatures during the rainy season (sowing season) shorten the crop cycle because the rate of degree-day accumulation is faster (Reis et al. 2020). In this sense, tolerant cultivars adapted to high-temperature conditions can be a strategy to keep crops productive on the MATOPIBA agricultural frontier.

In the MATOPIBA region, the average annual rainfall is $1,502.75 \mathrm{~mm}$ distributed mostly ( $88.75 \%)$ between Oct and Apr (Fig. 7). The highest rainfall levels occur in the Southwest, especially in the region 
predominated by Tocantins state, with high levels of rainfall distributed evenly during the rainy season (Oct-Apr), varying substantially only in Apr. High rainfall levels are also registered in the Southern of Maranhão and extreme West of Bahia. However, spatial reduction of rainfall indices occurs towards the Northeast region of MATOPIBA, especially in Piauí state, which has an average annual rainfall of $1,080.93 \mathrm{~mm}$. Between May and September (Sep), the lowest levels of rain are observed, below $170 \mathrm{~mm}$, a fact that shows the irregularity in the spatial distribution of rainfall.

Rainfall scenario in the MATOPIBA region is modulated by atmospheric systems at different scales, which associated with ecosystem and physiographic factors (as a transition between biomes) strongly influence the intra-seasonal variability of precipitation in the region (Valadão et al. 2017; Reis et al. 2020). However, even though the atmospheric systems formed by the equatorial positioning of the Intertropical Convergence Zone (ITCZ) and the South Atlantic Convergence Zone (SACZ) determine the occurrence of rainfall indices (Grimm 2011; Oliveira et al. 2017), the different levels of rainfall between Southwest and Northeast portion of MATOPIBA can be explained by the fact that the Northeast portion is located in transition biome between Cerrado and Caatinga (semiarid), having less influence of atmospheric systems. However, the Southwest portion is located in the transition of Cerrado and Amazon biomes, with about $100 \%$ of its surface in an Amazonian environment (Reis et al. 2020), therefore, influenced by atmospheric systems. Thus, the variable accumulation of rainfall in the MATOPIBA sub-regions is influenced by different vegetative configurations (Reis et al. 2020).

Real evapotranspiration is related to rainfall regime of the region because its occurrence is associated with the availability of water in the soil-plant system, being the main way to quantify the loss of water present in soil and plant for atmosphere (Milly; Dunne 2016). Thus, evapotranspiration in the MATOPIBA region occurs more intensely only during the rainy season (Oct-May), with average real evapotranspiration of $1,044.49 \mathrm{~mm}$ and a greater quantity of evapotranspirated water in the Southwest of MATOPIBA (Fig. 8). On the other hand, evapotranspiration values less than $40 \mathrm{~mm}$ were recorded between Jun and Sep, mainly in the Central and Northeast regions of MATOPIBA.

Water surplus in the soil commonly occurs between November (Nov) and April (Apr) (Fig. 9), with a total accumulation of $479.57 \mathrm{~mm}$; in this period, rainfall indices above $100 \mathrm{~mm}$ are frequent in MATOPIBA (Fig. 7). The largest water surplus (150 at $200 \mathrm{~mm}$ ) is concentrated in the Northwest of MATOPIBA, specifically in the areas of Tocantins state that concentrate $47.48 \%$ of all water surplus. In Jun, July, Aug, Sep, and Oct there is no water surplus in the region due to low rainfall, an event that characterizes this period as dry season in MATOPIBA (Figs. 9F, 9G, 9H, 9l, and 9J). May presents a water surplus only in the extreme North of MATOPIBA, located in Maranhão, with $48.11 \%$ of all annual surplus and an average of $561.32 \mathrm{~mm}$ (Fig. 9E).

The water deficit is variable during all months of the year (Fig. 10). However, its concentration is greater from Jun to Sep and reaches all MATOPIBA territory, with a deficit average of $267.09 \mathrm{~mm}$, corresponding to $74.44 \%$ of all annual water deficit (Figs. 10F, 10G, 10H, and 10I). Water deficit below $5 \mathrm{~mm}$ was found in Jan, Feb, Mar, Apr, Nov, and Dec (Figs. 10A, 10B, 10C, 10D, 10K, and 10L), the period in which there are 
marked volumes of rain. In Oct, the water deficit was zero only in the Southwest of MATOPIBA, represented by Tocantins state; however, in other regions of MATOPIBA, the water deficit can reach 150 mm (Fig. 10J).

MATOPIBA region presented climatic classification variable with four distinct classes distributed vertically throughout its delimitation (Fig. 11). Humid regions (class B1 and B2) were classified in $35.04 \%$ of MATOPIBA, with subclasses B1wA'a' (20\%) and B2wA'a' (6\%) more frequent (Fig. 13A). Class humid B1 predominated in the South, Central, and North of Tocantins, and occurred in small parts of the territories of Bahia and Maranhão; while the class humid B2 classification was represented only in small portions of West of Tocantins.

Moist subhumid (C2) was the second class with the greatest extension in MATOPIBA, distributed in $68.71 \%, 38.34 \%, 14.21 \%$ and $81.65 \%$ of th e Maranhão, Bahia, Tocantins, and Piauí area, respectively (Fig. 11). In addition, it comprised the subclasses C2sA'a', C2w2A'a', and C2wA'a', with this latter class more frequently in the region (Fig. 13A). It highlights that these subclasses delimit the areas where the largest producer of soybeans, corn, cotton, and beans are found (Fig. 14), indicating that these classifications have more appropriate climatic conditions for the development and production of crops. Class dry subhumid (C1) represented $12.67 \%$ of MATOPIBA, and comprised the subclassifications C1dA'a', C1s2A'a', C1sA'a', and C2rA'a', being located in the Southwest portion of Piauí and part of West of Bahia. Among the subclasses found, C2WA'a', B1wA'a', and C1sA'a' showed the highest cumulative frequency (around 42\%) (Fig. 13A), indicating that the classifications are more comprehensive in MATOPIBA.

Air temperature and rainfall volume, in climate change scenarios, altered the climatic characterization of the MATOPIBA region with extinction and/or inclusion of climatic classes (Fig. 12). Scenarios with increased air temperature showed a reduction in areas of climate humid (B1), mainly in Tocantins, and expansion of the Moist subhumid (C2) and Dry subhumid (C1) classes from the East for West of MATOPIBA (Figs. 12A and 12B). In addition, environments characterized as Semiarid (D) were observed in areas of Southwest Piauí and West of Bahia, especially when the scenario was $+3.0^{\circ} \mathrm{C}$ (Fig. 12B).

With increasing air temperature, the most frequent climatic subclasses in MATOPIBA were Das'a', DdA'a', C1sA'a', B1wA'a', and C2wA'a' which presented an accumulative frequency around 76\% (Figs. 13B and 13C). Although these subclasses occur in both $+1.5^{\circ} \mathrm{C}$ and $+3.0^{\circ} \mathrm{C}$ scenarios, greater coverage of the classes Moist subhumid (C2wA'a'), Dry subhumid (C1sA'a'), and Semiarid (das'a') were found in scenarios of greater temperature increase (Figs. 12B and 13C). These results show that the increase in air temperature alters the climatic conditions of MATOPIBA, which would cause changes in the vegetative configurations of the region, resulting in changes in the transition of biomes, such as reduction of areas of the Cerrado biome and increase of environments with characteristics of biome Caatinga. In addition, the agricultural activity in the region would be drastically affected by climate change caused by the increase in temperature, resulting in risk climatic for the cultivation of plants, thus compromising the production of crops and the agroeconomic development of MATOPIBA. 
In Thornthwaite climatic index, the rainfall regime becomes the most influential parameter to determine the climatic classes. In scenarios with changes of $+30 \%$ in the rainfall regime, the humid class (B4, B3, B2, and B1) occupied $58.14 \%$ of the MATOPIBA region (Fig. 12C). However, a greater number of climatic subclasses was found in this scenario, with subclasses C1sA'a' (Dry subhumid), B2wA'a' (Humid), B3wA'a' (Humid), B1wA'a' (Humid), and C2wA'a' (Moist subhumid) occurring more frequently (Fig. 13D). The greater coverage of humid class in MATOPIBA environments, in addition to characterizing the extent of the Amazon biome, indicates that the climatic conditions presented would allow to expansion of agricultural areas, increase the number of harvests per year and increase crop productivity. Thus, the increase of $+30 \%$ in the rainfall regime becomes the most promising scenario for agroeconomic development in this region.

When the scenario is of reduction (-30\%) in the rainfall regime, the MATOPIBA region presented the climatic classes Moist subhumid (C2), Dry subhumid (C1), and Semiarid (D), with $40.12 \%$ of the area occupied by class $\mathrm{C} 1$ (Fig. 12D). The number of subclasses determined was lower with an expressive frequency of C1sA'a', DdA'a', DsA'a', and C2wA'a' (Fig. 13E). In this scenario, Semiarid environments expanded to areas which were previously classified as Dry subhumid (Fig. 11), in the Center-South portion of Maranhão, Southwest Piauí, and part of West of Bahia. The West region of Tocantins was classified as Moist subhumid, while the Dry subhumid class occupied the Central, North, and South portion of MATOPIBA.

In the scenario of lower rainfall, both the Cerrado biome environments and the transition areas, between Cerrado and Caatinga biomes, can be reduced in the MATOPIBA region; however, areas of the Caatinga biome may increase as the Semiard class expands. In addition, the scenario of reduction in the rainfall regime negatively impacts agricultural activity because with low water availability in the soil the plants reduce their photosynthetic efficiency and, consequently, do not reach their productive potential (Taiz et al. 2017).

Productive areas located in environments of transition between biomes require technological efforts that encourage an increase in crop production (Araújo et al. 2019), because, in a transition environment between different biomes, ecosystems and climatic conditions are highly diversified, making these areas particularly vulnerable to climate change (Silva et al. 2016). In this sense, areas of MATOPIBA with high production of soy, corn, cotton, and beans would have a strong impact of climate change, since they are located largely in environments of transition from the Cerrado and Caatinga biomes (Fig. 14).

Regions of the extreme West of Bahia, South of Maranhão, and Southwest of Piauí present the largest productions of soy, corn, cotton, and beans (Fig. 14), being environments classified as Moist subhumid climate. However, in climate change scenarios with increased temperatures and reduced rainfall, these regions suffer changes in climatic conditions, with transition of climate classes between Moist subhumid, Dry subhumid, and Semiarid (Figs. 12B and 12D).

In the perspective of climate change, studies by Zilli et al. (2020) suggest a reduction in crop production, such as soybeans and corn, in areas of the Cerrado biome, mainly in the MATOPIBA region, with the 
displacement of productive areas to subtropical regions of the Atlantic Forest. However, part of the impact of climate change on MATOPIBA could be offset by increased productivity, which would maintain the agricultural scenario of region. Thus, efforts are required to invest in technology and changes in management processes, such as adapting the sowing schedule for crops, using drought-resistant cultivars, using irrigation, efficiency in crop fertilization, improving structural and soil conditions, soil fertility, and precision agriculture (Zilli et al. 2020). Therefore, following these strategies makes it possible to adapt the crops to the climatic conditions of the region and may increase or maintain the productive potential of the crops, alleviating the impacts caused by climate change.

\section{Conclusions}

MATOPIBA region has air temperature, rainfall and real evapotranspiration averages of $26.28^{\circ} \mathrm{C}, 1,502.75$ $\mathrm{mm}$, and 1,044.49 mm, respectively, with the rainy seasons, between October and April, and drought, from May to September, well defined. In addition, this region is characterized by a humid climate (B1 and B2), dry subhumid (C1), and Moist subhumid (C2). However, in climate change scenarios, climatic extreme indices tend to change the pattern, frequency, and distribution of climate class, which can result in increased climate risk conditions for agricultural activity in the MATOPIBA region, generating negative socioeconomic impacts. Therefore, the results obtained can be used to develop strategies to mitigate the vulnerability of crops to climate change conditions.

\section{Declarations}

\section{Compliance with ethical standards}

Conflict of interest The authors declare that they have no conflict of interest.

Funding Statement: This study was financed in part by the IFSULDEMINAS Campus Muzambinho.

Availability of data and material: The data/ material is opened

Code availability: The software used was python and scripts are available

Ethics approval: It is not necessary

Consent to participate: All authors approved

Consent for publication: All authors approved

\section{References}

Acompanhamento de safra brasileira de grãos. CONAB (2020). v. 7 Safra 2019/20 - Quarto levantamento, Brasília, p. 1-104. 
Araújo MLS, Sano EE, Bolfe ÉL, Santos JRNJ, Santos JS, Silva FB (2019) Spatiotemporal dynamics of soybean crop in the MATOPIBA region, Brazil (1990-2015). Land Use Policy 80: 57-67. https://doi.org/10.1016/j.landusepol.2018.09.040.

Elguindi N, Grundstein A, Bernardes S, Turuncoglu U, Feddema J (2014)Assessment of CMIP5 global model simulations and climate change projections for the $21^{\text {st }}$ century using a modified Thornthwaite climate classification. Climatic Change 122: 523-538. https://doi.org/10.1007/s10584-013-1020-0

Grimm AM (2011) Interannual climate variability in South America: impacts on seasonal precipitation, extreme events and possible effects of climate change. Stochastic Environmental Research and Risk Assessment 25(4): 537-554.

Halder D, Kheroar S, Srivastava RK, Panda RK (2020) Assessment of future climate variability and potential adaptation strategies on yield of peanut and Kharif rice in eastern India. Theoretical and Applied Climatology 140: 823-838. https://10.1007/s00704-020-03123-5

IBGE. (2010) Censo. Rio de Janeiro. Disponível em: http://censo2010.ibge.gov.br/ Acesso em: 1 jun. 2020.

Milly P, Dunne K (2016) Potential evapotranspiration and continental drying. Nature Climate Change 6: 946-949.

Oliveira PT, Silva CMS, Lima KC (2017) Climatology and trend analysis of extreme precipitation in subregions of Northeast Brazil. Theoretical and Applied Climatology 130(1-2): 77-90.

Pirttioja N, Carter TR, Fronzek S, Bindi M, Hoffmann H, Palosuo T, Ruiz-Ramos M, Tao R, Trnka M, Acutis M, Asseng S, Baranowiski P, Basso B, Bodin P, Buis S, Cammarano D, Deligios P, Destain M-F, Dumont B, Ewert F, Ferrise R, François L, Gaiser T, Hlavinka P, Jacquemin I, Kersebaum KC, Kollas C, Krzyszczak J, Lorite IJ, Minet J, Minguez MI, Montesino M, Moriondo M, Müller C, Nendel C, Öztürk I, Perego A, Rodríguez A, Ruane AC, Ruget F, Sanna M, Semenov MA, Slawinski C, Stratonovitch P, Supit, Waha K, Wang E, Wu L, Zhao Z, Rötter RP (2015) Temperature and precipitation effects on wheat yield across a European transect: a crop model ensemble analysis using impact response surfaces. Climate Research 65: 87-105.

Rausch LL, Gibbs HK, Schelly I, Brandão Junior A, Morton DC, Carneiro Filho A, Strassburg B, Walker N, Noojipady P, Barreto P, Meyer D (2019) Soy expansion in Brazil's Cerrado. Conservation Letters 12(6): e12671. https://doi.org/10.1111/conl.12671

Reis LC, Silva CMS, Bezerra BG, Mutti PR, Spyrides MHC, Silva PE (2020) Analysis of Climate Extreme Indices in the MATOPIBA Region, Brazil. Pure and Applied Geophysics 177: 4457-4478. https://doi.org/10.1007/s00024-020-02474-4. 
Rolim GS, Camargo MBP, Lania DG, Moraes JFL (2007) Classificação climática de Köppen e de Thornthwaite e sua aplicabilidade na determinação de zonas agroclimáticas para o estado de São Paulo. Revista Bragantia 66(4): 711-720.

Silva FB, Santos JRN, Feitosa FECS, Silva IDC, Araújo MLS, Guterres CE, Santos JS, Ribeiro CV, Bezerra DS, Neres RL (2016) Evidências de mudanças climáticas na região de transição Amazônia-Cerrado no estado do Maranhão. Revista Brasileira de Meteorologia 31: 330-336.

Silva JA, Santos PAB, Carvalho LG, Moura EG, Andrade FR (2020) Gas exchanges and growth of soybean cultivars submitted to water deficiency. Pesquisa Agropecuária Tropical 50: e58854.

Silva VPR, Silva ERA, Maciel GF, Souza EP, Braga CC, Holanda RM (2020) Soybean yield in the MATOPIBA region under climate changes. Revista Brasileira de Engenharia Agrícola e Ambiental 24(1): 8-14. https://doi.org/10.1590/1807-1929/agriambi.v24n1p8-14

Sun X, Li J, Zhou A (2017) Evaluation and comparison of methods for calculating Thornthwaite moisture index. Australian Geomechanics 52(2): 61-75.

Taiz L, Zeiger E, Møller IM, Murphy A (2017) Fisiologia e desenvolvimento vegetal. Artmed Editora.

Thornthwaite CW, Mather JR (1955) The water balance. Centerton: Drexel Institute of Technology. Laboratory of Climatology 8(1): 104.

Thornthwaite CW (1948) An approach toward a rational classification of climate. Geographical review 38(1): 55-94.

Valadão CEA, Carvalho LMV, Lucio PS, Chaves RR (2017) Impacts of the madden-Julian oscillation on Intraseasonal precipitation over Northeast Brazil. International Journal of Climatology 37: 1859-1884.

Vendrame PRS, Brito OR, Martins ES, Quantin C, Guimaraes MF, Becquer T (2013) Acidity control in latosols under long-term pastures in the Cerrado region, Brazil. Soil Research 51: 253-261. https://doi. org/10.1071/sr12214

Wang C, Linderholm HW, Song Y, Wang F, Liu Y, Tian J, Xu J, Song Y, Ren G (2020) Impacts of drought on maize and soybean production in northeast china during the past five decades. International Journal of Environmental Research and Public Health 17: 2459.

\section{Figures}



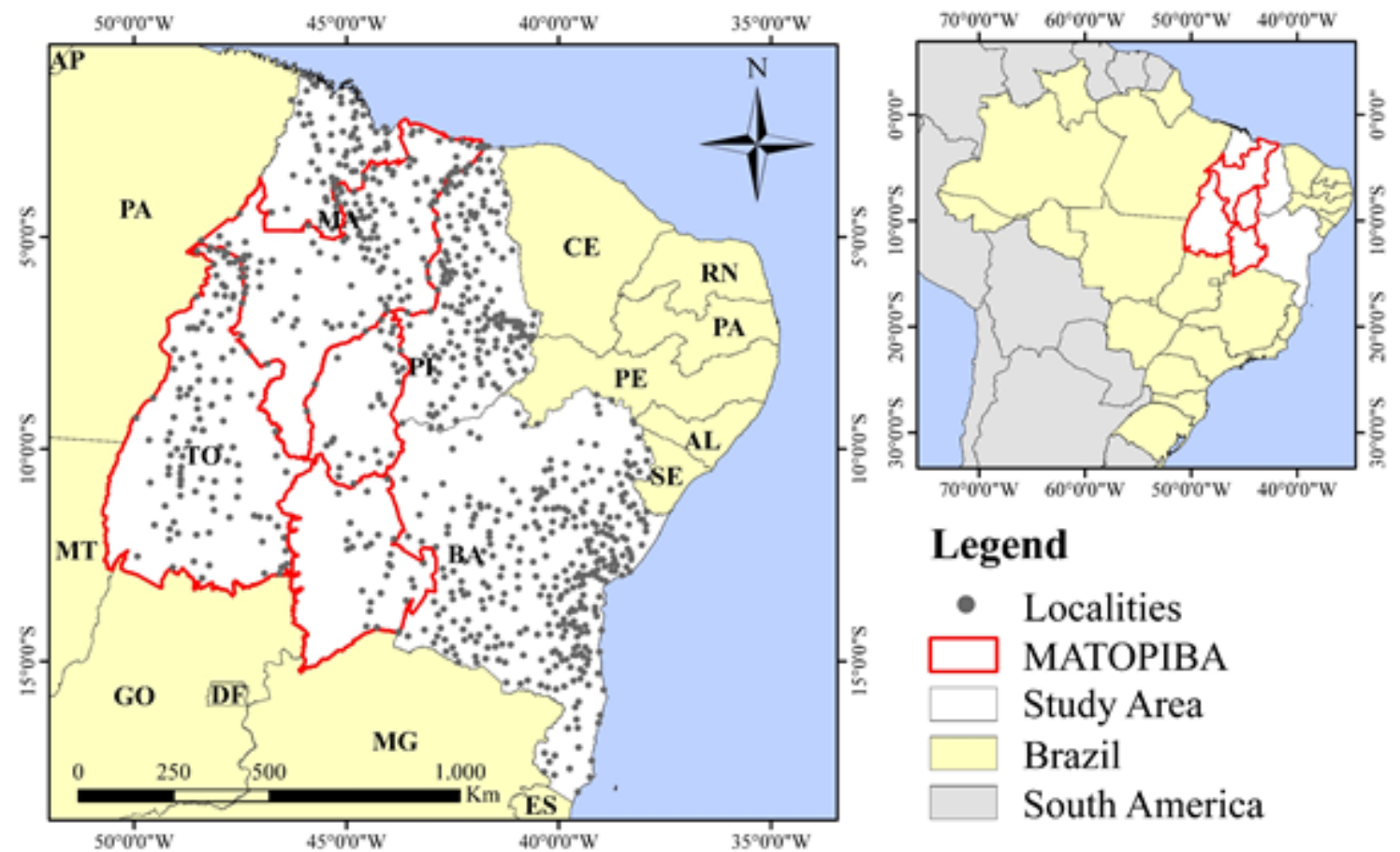

Figure 1

Geographical location of region MATOPIBA in the states of Maranhão, Tocantins, Piauí, and Bahia, Brazil. 


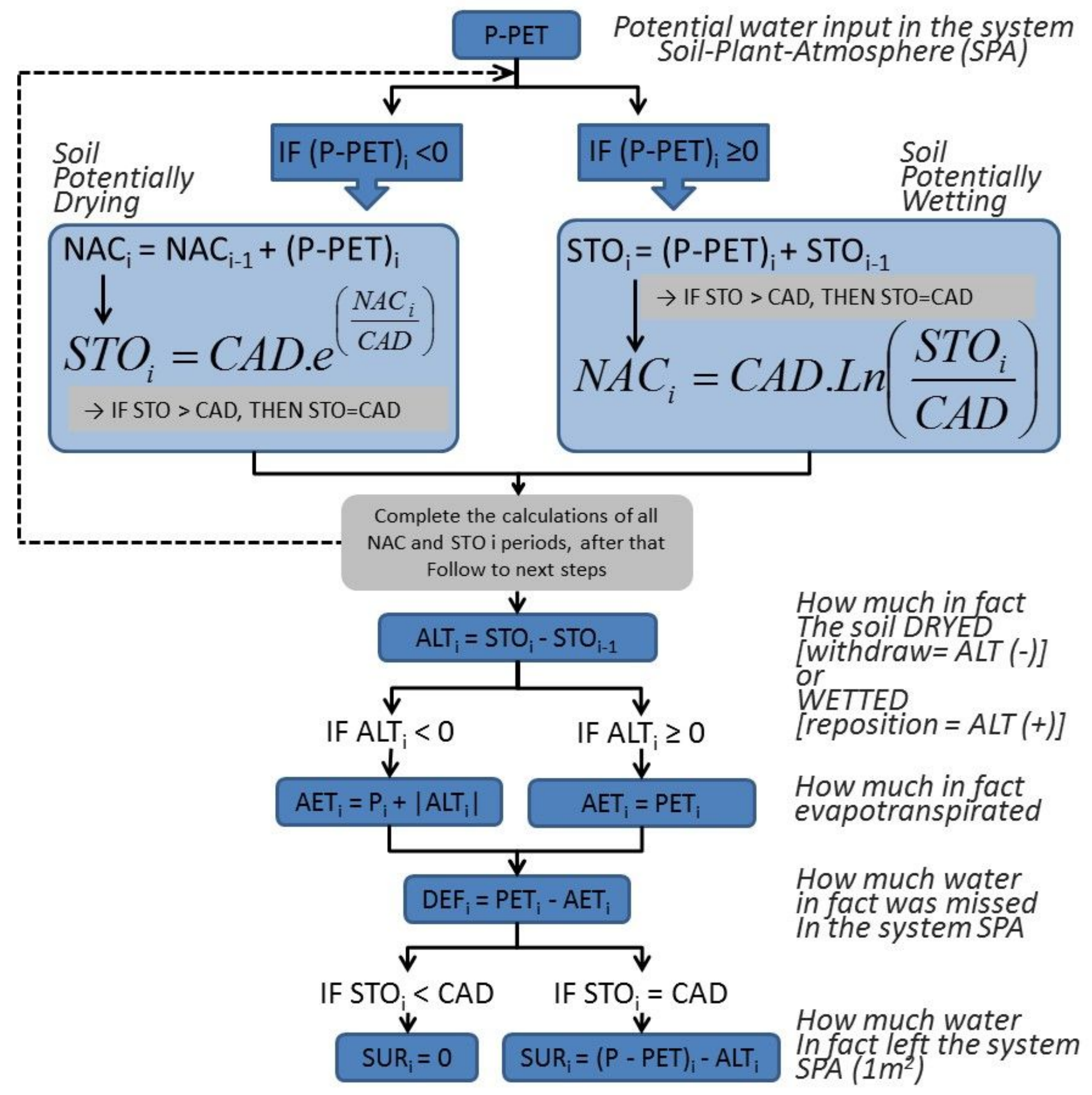

Figure 2

Flowchart of the water balance model modified from Thornthwaite and Mather (1955). Legend: CAD is the soil water capacity $(\mathrm{mm}), \mathrm{NAC}$ is the negative accumulated $(\mathrm{mm})$, meaning the potential drying of the soil, ALT is the alteration of STO, and i a given period, $\mathrm{i}-1$ previous period. 


\section{Adequacy of moisture}

Moisture index (Im)
A : Perhumid
B4: Humid
B3: Humid
B2: Humid
B1: Humid
C2: Moist subhumid
C1: Dry subhumid
D: Subhumid
E: Arid

Seasonal moisture distribution

Aridity index (Ia)

r: little or no water deficiency

s: moderate summer water deficiency

w: moderate winter water deficiency

s2: large summer water deficiency

w2: large winter water deficiency

Hydric index (Ih)

d: little or no water surplus

s: moderate summer water surplus

w: moderate winter water surplus

s2: large summer water surplus

w2: large winter water surplus
Thermal efficiency

Potential anual

evapotranspiration (PET)

A' : Megatherrmal

B'4: Mesothermal

B'3: Mesothermal

B'2: Mesothermal

B'1: Mesothermal

C'2: Microthermal

C'1: Microthermal

D': Tundra

E': Frost
Thermal efficiency in summer

Potential summer evapotranspiration (PET) a':PET $\leq 48.0 \%$ total annual

b'4: PET 48.0 to $51.9 \%$ total annual b'3: PET 51.9 to $56.3 \%$ total annual b'2: PET 56.3 to $61.6 \%$ total annual b'1: PET 61.6 to $68.0 \%$ total annual c'2: PET 68.0 to $76.3 \%$ total annual c'1: PET 76.3 to $88.0 \%$ total annual d': PET $\geq 88.0 \%$ total annual
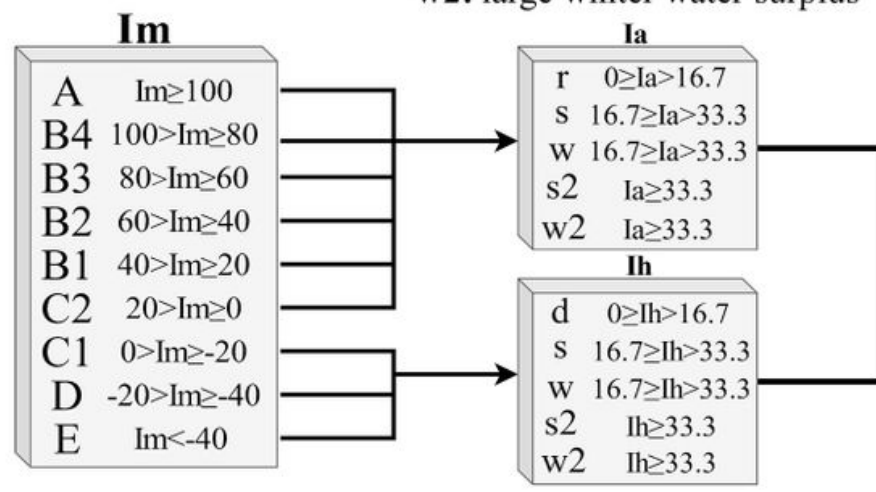

\begin{tabular}{|cc}
\multicolumn{1}{c}{ PETyear $(\mathbf{m m})$} \\
\hline $\mathrm{A}^{\prime}$ & $\mathrm{PET} \geq 1140$ \\
$\mathrm{~B}^{\prime} 4$ & $1140 \geq \mathrm{PET}>856$ \\
$\mathrm{~B}^{\prime} 3$ & $997>\mathrm{PET} \geq 856$ \\
$\mathrm{~B}^{\prime} 2$ & $855>\mathrm{PET} \geq 712$ \\
$\mathrm{~B}^{\prime} 1$ & $712>\mathrm{PET} \geq 570$ \\
$\mathrm{C}^{\prime} 2$ & $570>\mathrm{PET} \geq 428$ \\
$\mathrm{C}^{\prime} 1$ & $427>\mathrm{PET} \geq 285$ \\
$\mathrm{D}^{\prime}$ & $285>\mathrm{PET} \geq 142$ \\
$\mathrm{E}^{\prime}$ & $\mathrm{PET}<142$
\end{tabular}

PETsummer (\%)

a' $\quad$ PET $\leq 48.0 \%$

b'4 $48.0<$ PET $\leq 51.9$

b'3 $51.9<\mathrm{PET} \leq 56.3$

b'2 $56.3<\mathrm{PET} \leq 61.6$

b'1 $61.6<\mathrm{PET} \leq 68.0$

c'2 $68.0<$ PET $\leq 76.3$

c'1 $76.3<$ PET $\leq 88.0$

d' $\quad$ PET $\geq 88.0$

\section{Figure 3}

Criteria used in the classification of Thornthwaite.

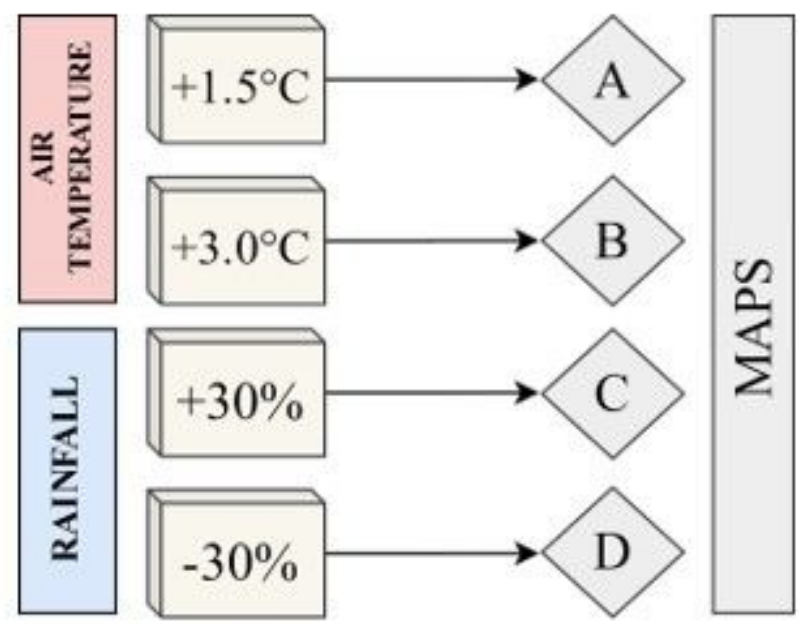

\section{Figure 4}




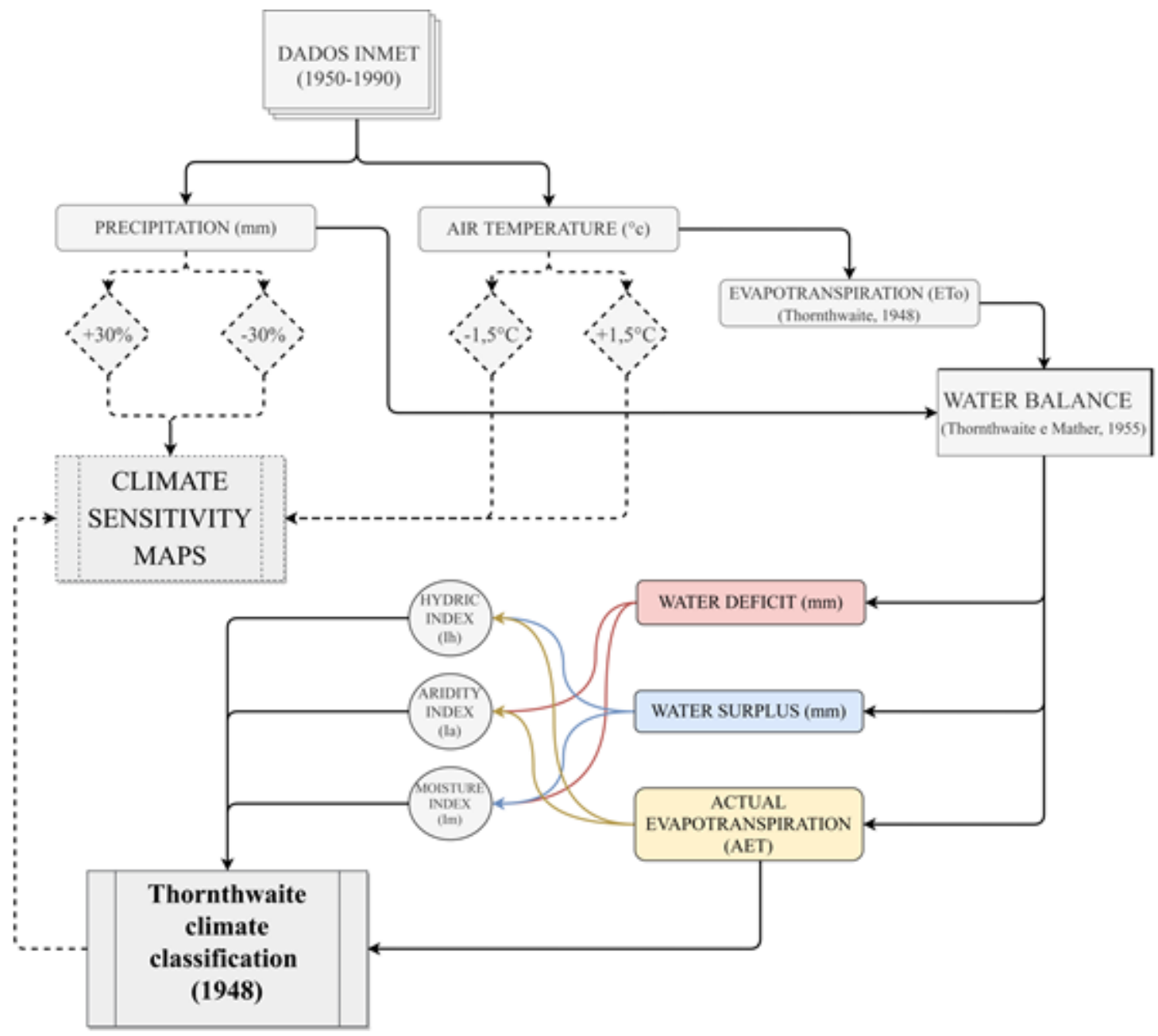

Figure 5

Flowchart representing the steps taken to obtain the Thornthwaite climate classification. 

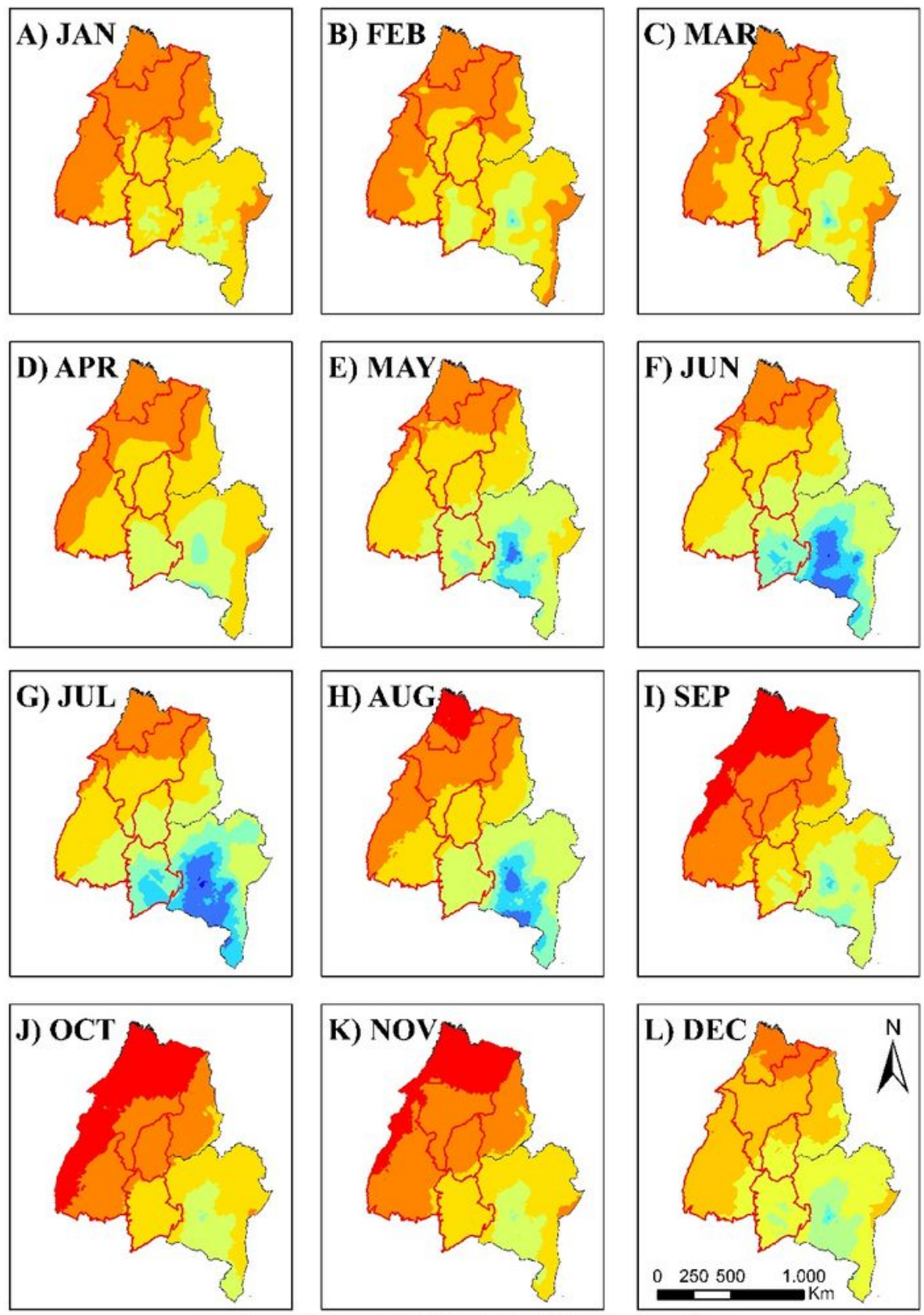

AIR TEMPERATURE $\left({ }^{\circ} \mathrm{C}\right)$

$\square<18 \square 21-22 \square 26-28$
$18-20 \square 22-24 \square 28-30$
$20-21 \square 24-26 \square>30$

Figure 6

Spatial variability of mean monthly air temperature in the MATOPIBA region of Brazil. 

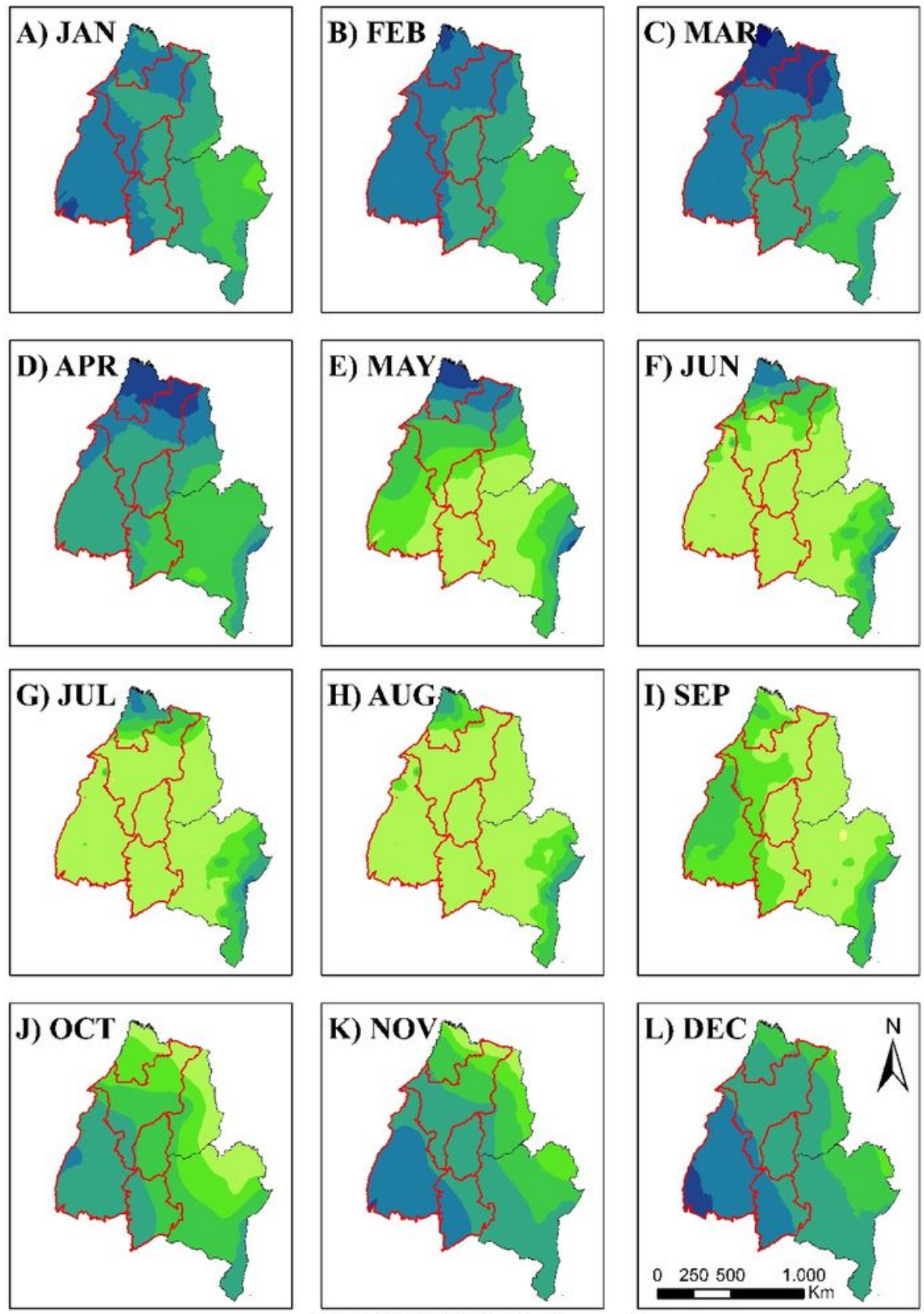

RAINFALL (mm)

$\square 0 \quad \square 26-50 \square 101-200 \square 301-400$
$\square 1-25 \square 51-100 \square 201-300 \square 401-500$

Figure 7

Spatial variability of mean monthly precipitation in the MATOPIBA region of Brazil. 

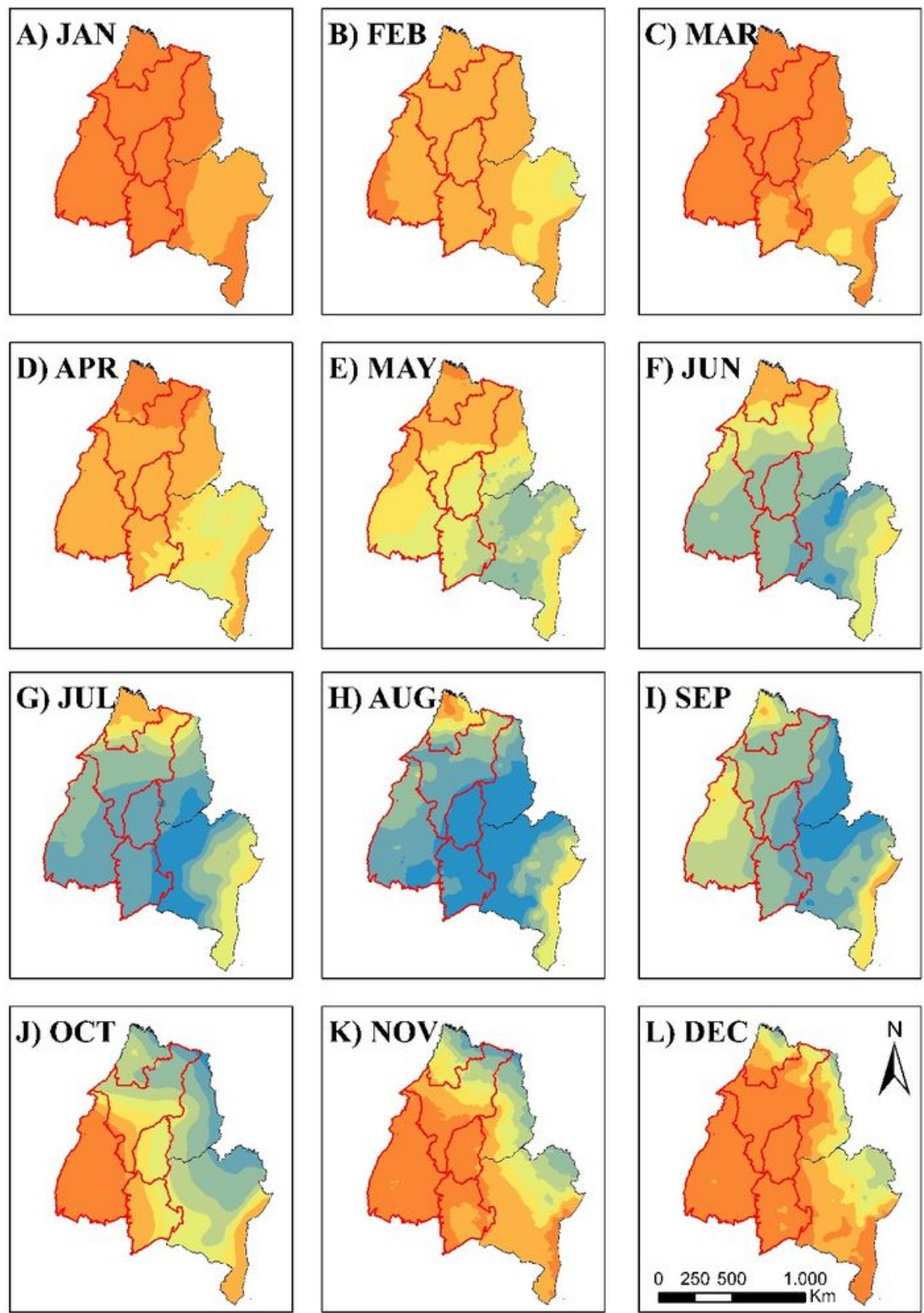

\section{REAL EVAPOTRANSPIRATION (mm)}

$<10 \square 21-40 \square 61-80 \square 110-120 \square 150-160$
$11-20 \square 41-60 \square 81-100 \square 130-140 \square>160$

Figure 8

Spatial variability of mean monthly real evapotranspiration in the MATOPIBA region of Brazil. 

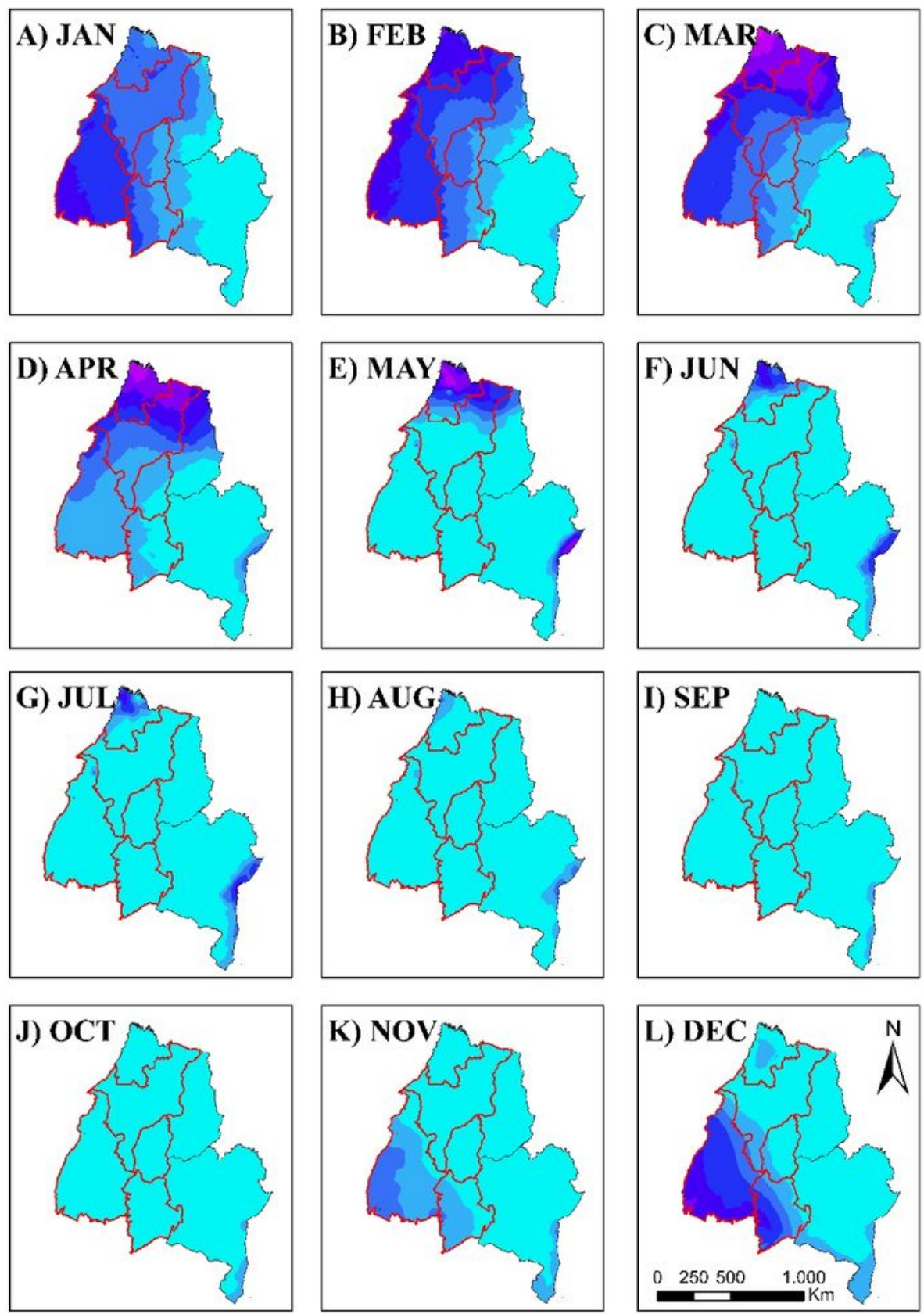

\section{WATER SURPLUS (mm)}

$\square 0-5 \square 50-100 \square 150-200 \square 250-300$
$\square 5-50 \square 100-150 \square 200-250 \square>300$

Figure 9

Spatial variability of mean monthly water surplus in the MATOPIBA region of Brazil. 

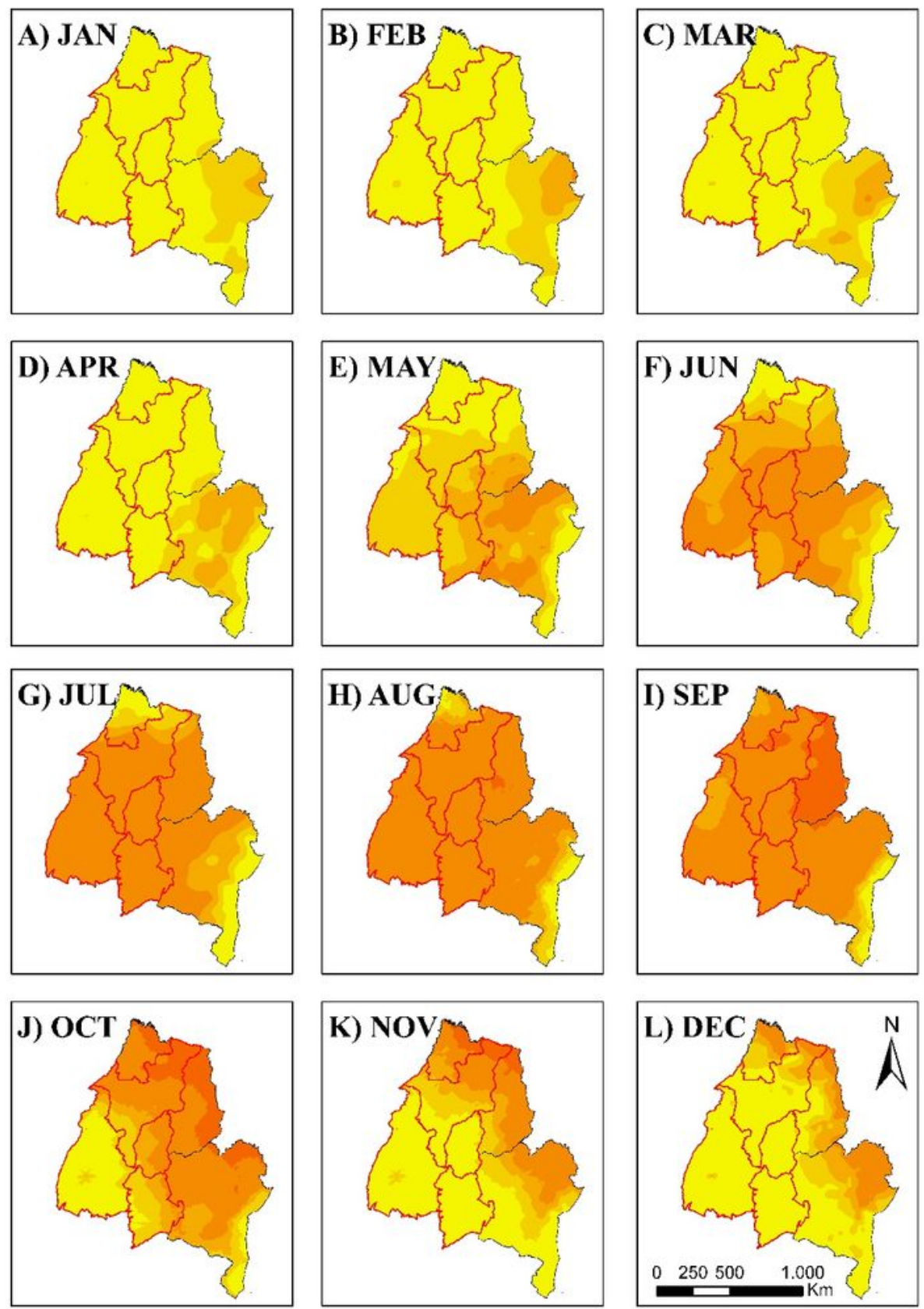

\section{WATER DEFICIT (mm)}

$\square<5 \square 25-50 \square 100-150 \square 200-300$
$\square 5-25 \square 50-100 \square 150-200 \square>300$

Figure 10

Spatial variability of mean monthly water deficit in the MATOPIBA region of Brazil. 


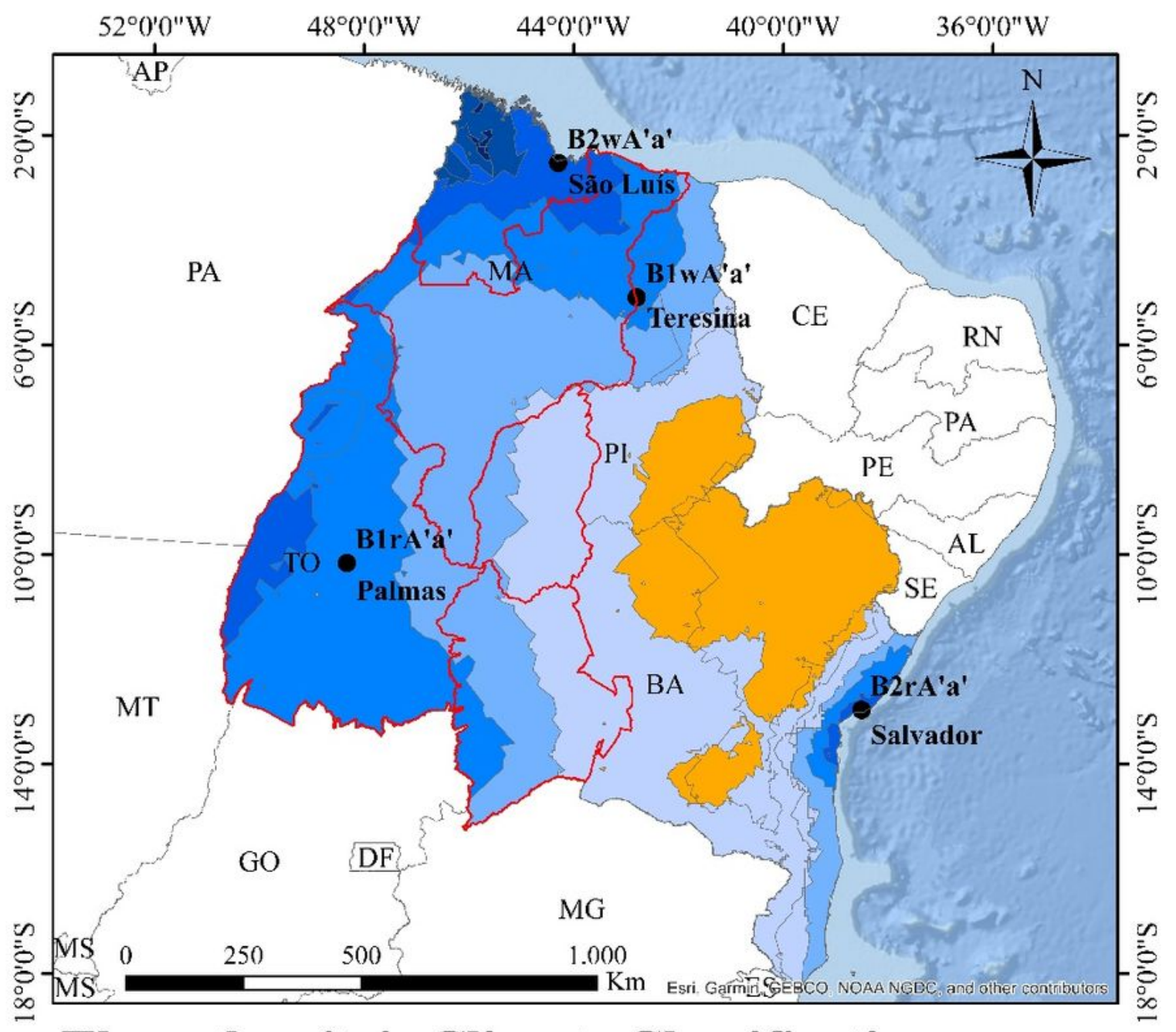

\section{Thornthwaite's Climate Classification}

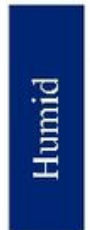

B4rA'a'
B4wA'a'
B3rA'a'
B3sA'a'
B3wA'a'
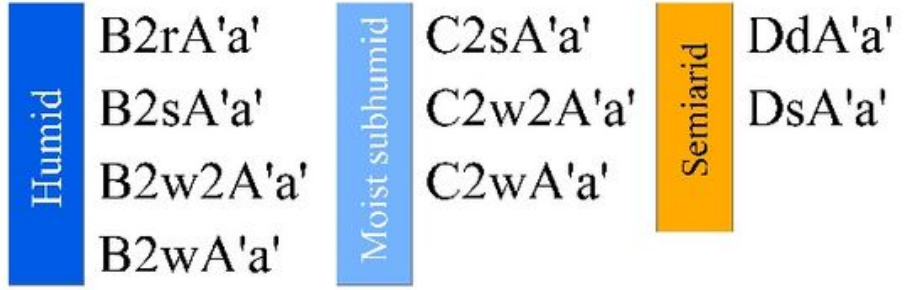

B3rA'a'
B3sA'a'
B3wA'a'

B1rA'a'
B1sA'a'
B1w2A'a'
B1wA'a'

\begin{tabular}{l|l}
$\mathrm{C} 1 \mathrm{dA}^{\prime} \mathrm{a}^{\prime}$ \\
$\mathrm{C} 1 \mathrm{~s} 2 \mathrm{~A}^{\prime} \mathrm{a}^{\prime}$ \\
$\mathrm{C} 1 \mathrm{sA} \mathrm{a}^{\prime}$ \\
$\mathrm{C} 2 \mathrm{rA}^{\prime} \mathrm{a}^{\prime}$
\end{tabular}

Figure 11

Spatial variability of the Thornthwaite (1948) climate index for MATOPIBA region of Brazil. 

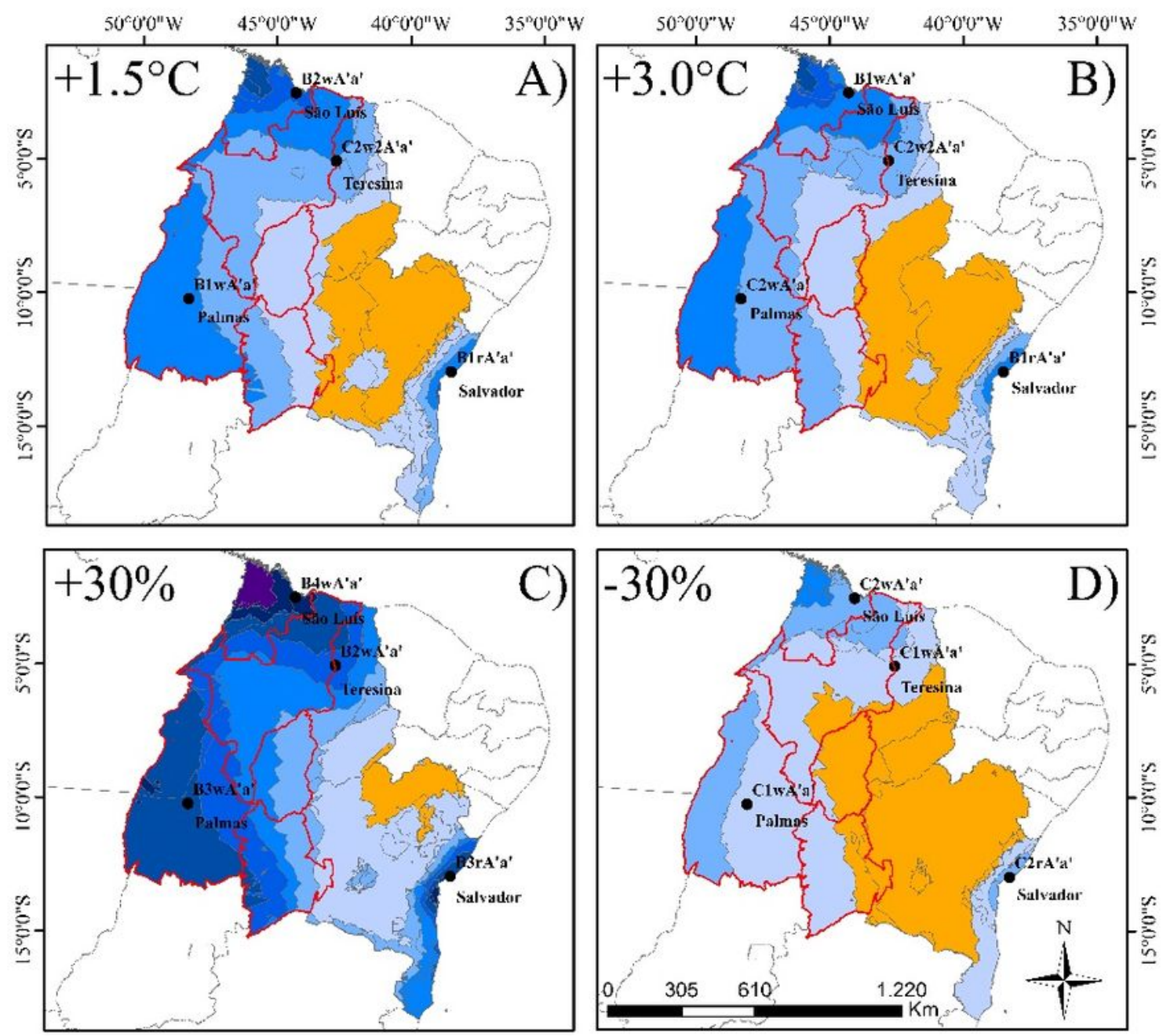

\section{Thornthwaite's Climate Classification}

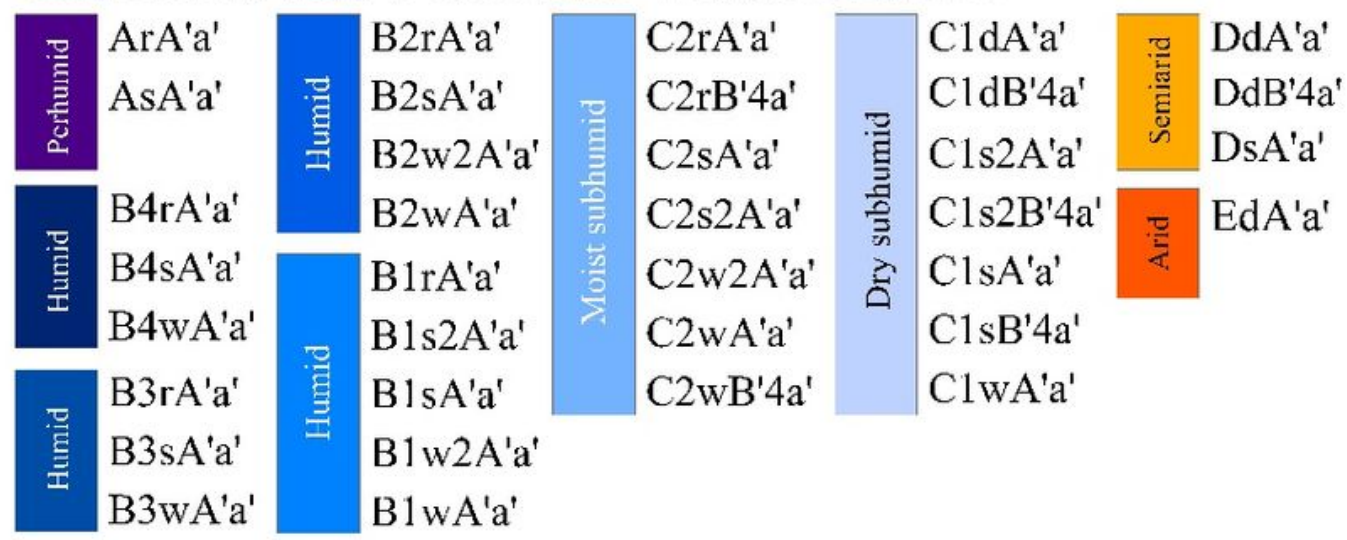

Figure 12

Spatial variability of the Thornthwaite (1948) climate index in scenarios of changes in air temperature and rainfall for MATOPIBA region of Brazil. 

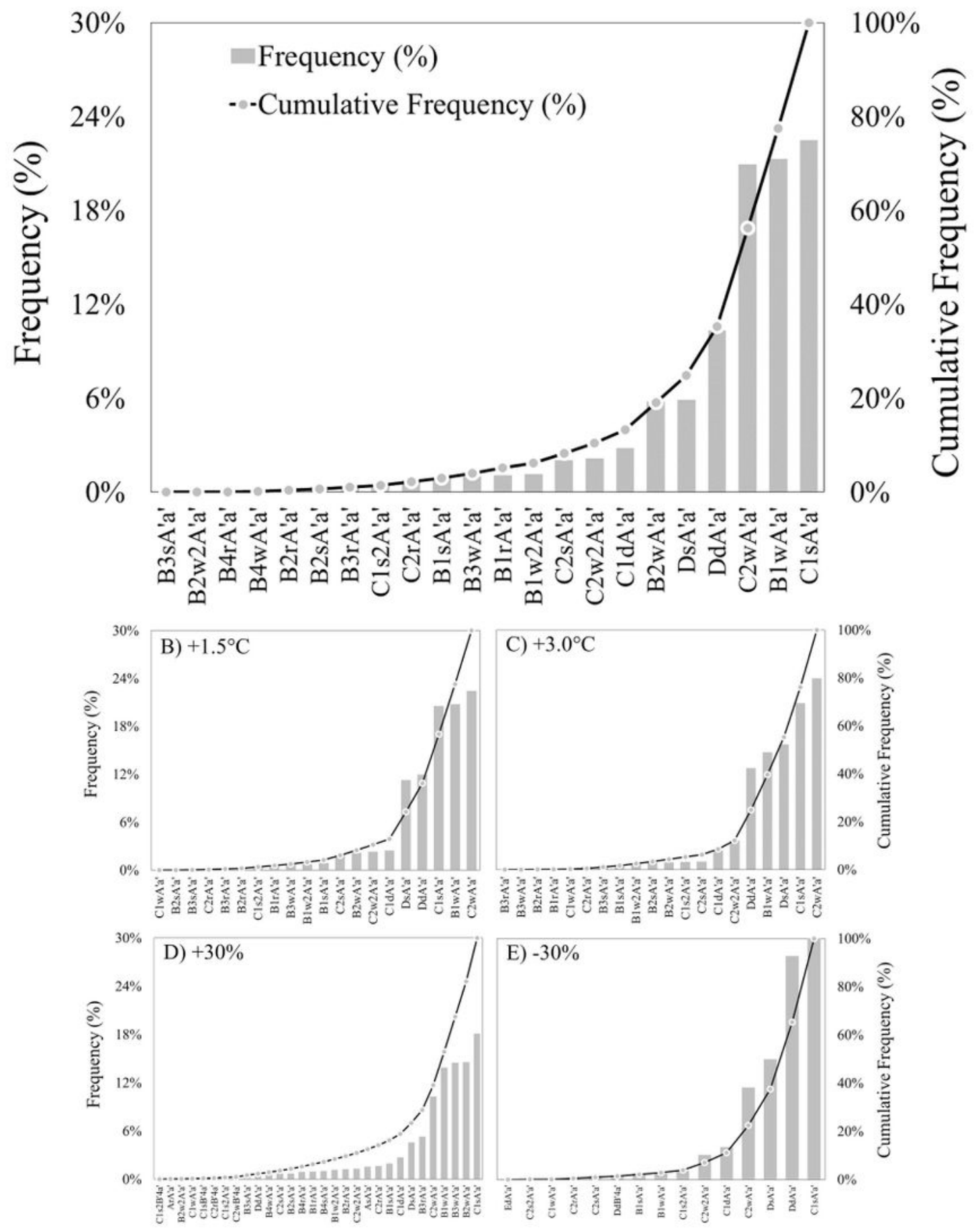

Figure 13

Frequency of the Thornthwaite (1948) climate index in scenarios of changes in air temperature and rainfall for MATOPIBA region of Brazil. 


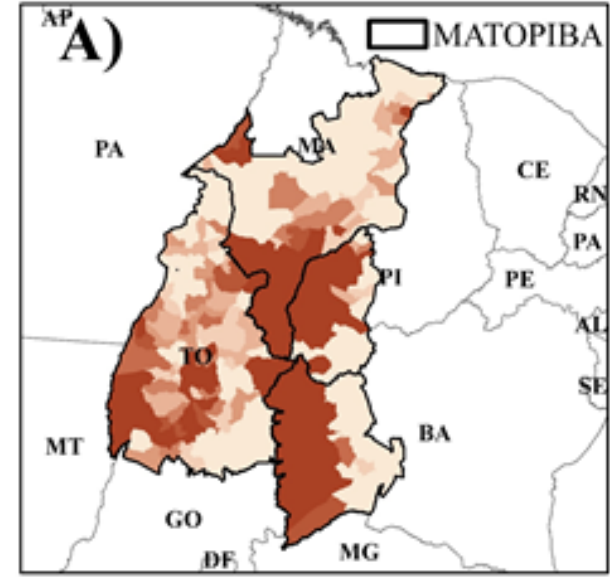

SOY PRODUCTION (t)
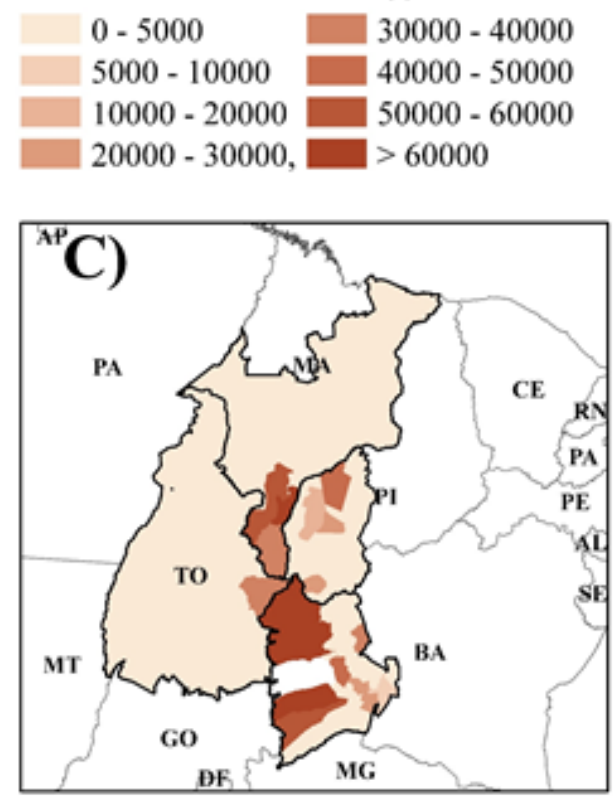

COTTON PRODUCTION (t)

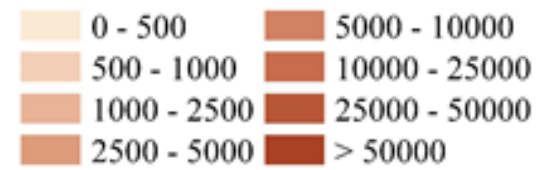

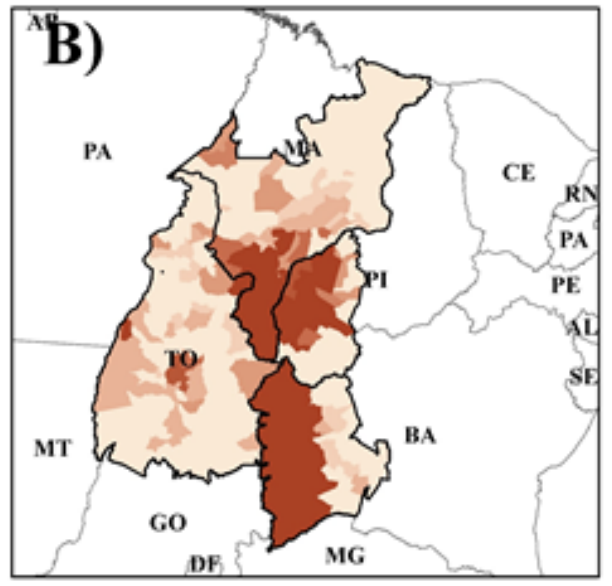

\section{CORN PRODUCTION (t)}
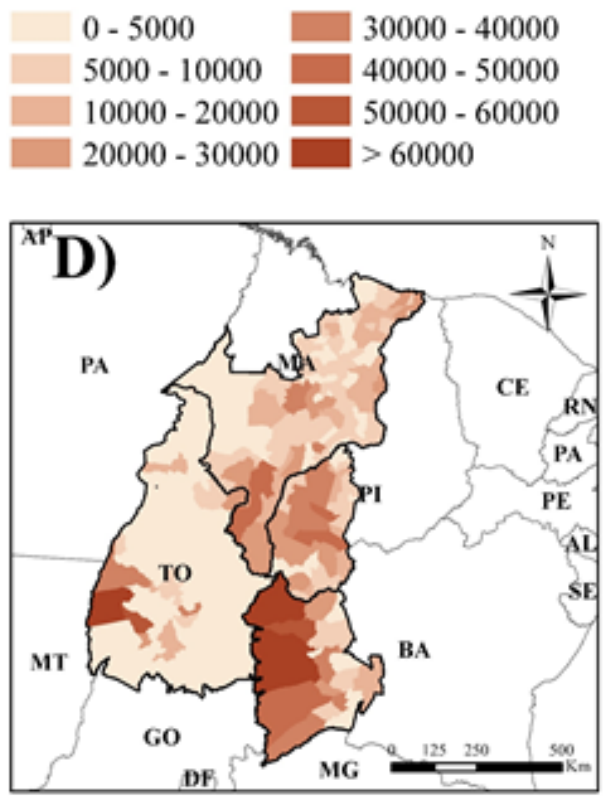

BEAN PRODUCTION (t)

$0-100 \square 1000-2500$

$100-250 \square 2500-5000$

$250-500 \square 5000-7500$

$500-1000 \square>7500$

\section{Figure 14}

Spatial variability in the production of the main crops in the MATOPIBA region of Brazil. Source: CONAB (2020). 